\title{
Exploration on the Reform of Class Teaching Mode of Art Theory Course in Colleges and Universities
}

\author{
Tana \\ Department of Fine Arts, Hohhot Minzu College, Hohhot, Inner Mongolia 010051
}

Keywords: college art; theory class, classroom teaching mode, reform

\begin{abstract}
With the reform and adjustment of syllabus, the content and mode of art teaching in colleges and universities are also constantly improving. Although art courses in colleges and universities are practice-based disciplines, practice is formed on the basis of theory. Therefore, the theoretical courses of fine arts are even more important. Nowadays, due to the fact that university students pay more attention to the practical activities of fine arts, and regard their own drawing skills and hands-on ability, the theoretical system of fine arts is neglected and abandoned. Therefore, university teachers should start from the theoretical aspects to cultivate their art ability. This article will explore and analyze the reform of the classroom teaching mode of art theory course in colleges and universities.
\end{abstract}

\section{Introduction}

The course content of theoretical courses in college art tends to make the students feel dull and boring. The students are not interested in the theoretical knowledge of art in colleges or universities and the spirit of the course, thus affecting the art courses in colleges and universities. Therefore, if students want to gain some experience in art theory courses in colleges and universities and enjoy the fun of art study, they should reform and innovate from the teaching mode, enhance the students' interest through diversified teaching modes and make the students immersed in art theory courses and for the practice of art to lay a solid foundation.

\section{The traditional university art theory class classroom teaching model problems}

Traditional college art theory class classroom teaching model is relatively old, mainly to explain the teacher, thus giving students the theory of art courses under pressure. The author will analyze the problems that appear in the teaching mode of traditional art theory courses in colleges and universities.

1) Student's main body position is not clear enough. In the traditional college art theory class classroom teaching, but also uphold the position of the teacher as the main body, so students can only serve as a supporting role in classroom teaching, blindly listen to teachers to explain dull art theory class classroom teaching, will make students lose interest in learning theoretical knowledge of art. In addition, the "inculcating" teaching mode will not allow students to improve their professional knowledge of art, and may even produce counterproductive results.

2) Serious single teaching mode. The traditional teaching mode of art theory course in colleges and universities is single, which will lead students to lose interest in art theory course, but will also produce annoying psychological emotion. Over time, students cannot master the art theoretical knowledge system, which not only affects the theoretical exam scores at the end of the period, but also hinders the application of fine arts practice and seriously affects the overall improvement of fine arts.

3) There is no connection between theory teaching and practice. In the traditional art theory teaching in colleges and universities, teachers simply explain the theoretical knowledge of art for students, and occasionally introduce students to art masters or fine art works. However, it did not tell students how to pass the master's works, extract the essence among them, and apply them to the actual art painting or the design of their works. As a result, students' theory and practice are 
separated and the art theory teaching is affected.

4) Teacher's traditional thinking is deeply rooted. Some teachers in colleges and universities do not want to change the traditional teaching mode, but because teachers' thinking is limited, they cannot exert their own imagination to create brand-new teaching mode. And in many art teachers in colleges and universities have more advanced qualifications and older ages. Therefore, their relatively less understanding of innovation and the trend of art culture in the modern era has seriously affected the reform of the teaching mode of art theory courses.

\section{College art theory class classroom teaching reform measures}

With the reform and innovation of college syllabus, the teaching mode of art theory classroom in colleges and universities in our country is also evolving constantly. Therefore, I will discuss the reform measures.

1) Let art classroom teaching and life combination. Art comes from life, but above life. Art belongs to one of the eight major art categories, art theory courses in colleges and universities should come from life. Therefore, the teaching mode of art theory classroom should be in good connection with daily life. In the art theory courses to explain, teachers cannot blindly impart to the students theoretical knowledge and skills, or teaching materials to the key points to the students, so that students understand and recite their own, the boring art teaching mode will make the students lose confidence and interest in the art, over time, students master the art of theoretical knowledge and painting skills will not only improve but will decline. Therefore, teachers can incorporate the contents of art textbooks into the reality of life so that students can perceive the importance of art theory courses from their daily life and enhance students' interest in art theory learning. Teachers should arrange art teaching content according to local conditions and formulate reasonable art teaching plans and objectives so as to make the art theory course more life-oriented so as to enable students to broaden their horizons, develop their thinking, cultivate their innovative spirit and create their abilities through fine arts theoretical courses, at the same time also be able to establish friendly exchanges between teachers and students. For example, teachers should explain the knowledge of "Introduction to Art" before explaining any course of art theory. Through the knowledge system and integrity of the art introduction, teachers can promote the comprehensive development of the eight art categories, therefore, the theoretical knowledge of art is also extended according to "Introduction to Art," and when teachers explain the third chapter of art and social life, they can link the theory of art theory to the reality of life, teachers can lead students to outdoor viewing natural landscapes, and from natural landscapes to find a masterpiece created by the art of similar works, and lead students to analyze, and explain the artistic conception and characteristics of creative landscape painting so that students can effectively combine the life and art theoretical knowledge.

2) Explain the theory of fine arts through micro courses. Micro-curriculum is an emerging teaching mode developed at this stage, and now it has been applied to many courses in colleges and universities. For the teaching of art theory courses, micro-curriculum also plays an important role and significance and can potentially teach students the teaching methods according to their aptitudes. As students have different mastery of theoretical knowledge of art, it is impossible for teachers to solve all the art theoretical knowledge that students do not understand in a short period of time. At this time, students can observe the micro-courses to find out the gaps through the subclasses. Students can find the corresponding micro-courses according to the problems they do not know or know clearly, they can also be in the form of comments by the teacher to teach the art theory or do not understand the problem of questioning or scoring, teachers see the students of the message, will also be the first time to help students answer, this micro-curriculum teaching mode will not only allow students to master more art theory knowledge, but also will save students learning time, improve efficiency, so as to achieve a good art theory course learning effect. For example, teachers may explain different styles of art creation and genre in the teaching of each lesson. Some students with weak basic knowledge of art theory may not be able to keep up with the pace of teachers so that they can be better through micro-curricula In addition, teachers can also recommend some art-related micro-channel public platform for students so that students can 
develop their own theoretical knowledge of art and have a deeper understanding and understanding of fine arts based on the understanding of the contents of the class.

3) Use conversation method to stimulate students' interest. Talk teaching method is a relatively relaxed teaching methods, the same applies to the teaching of art theory, teachers blindly explain the students' dominant position cannot be reflected, therefore, their ideas and attitudes cannot be expressed, it will limit student imagination and creativity to play, therefore, teachers should adopt a light and enjoyable conversation teaching mode to arouse students' interest and enthusiasm so that all students can participate in art theory courses. Teachers should leave most of their time to students in art theory courses so that they can express themselves in class according to the information they find under their own class and their own ideas. Students can express their opinions not only to master the theoretical knowledge of fine arts, you can also pave the way for the practice of fine arts, so as to achieve the purpose and effect of double benefit. In addition, the interaction between students and teachers can make teachers more clearly understand the student's understanding of the theory of fine arts, and know the key points for the next step. This relaxed and enjoyable teaching mode will be more easily recognized by students. For example, when teachers explain the relevant theoretical knowledge of the Fauvism, they should first let the students read through the contents of the teaching materials and put forward their own doubts. After the teachers have answered the questions, they will start the conversation teaching method and the intense interaction between students and teachers will arouse students' interest in the Fauvism. At the same time, it will also help students to solve all the difficulties in one go. Students will have a deeper fierce influence on the representatives and works of the Fauvist. If there is still time after school, Teachers can lead students to imitate masterpieces, draw paintings based on the Fauvism's creative features, and allow teachers and other students to comment on the combination of theory and practice.

4) Art theory courses and specialized courses combined. Most art theory courses in colleges and universities include: "Introduction to Art", "Introduction to Fine Arts", "History of Chinese Painting", etc. The purpose of these art theory courses is to improve students 'artistic quality and level, as well as to provide a basis for students' art major courses. Therefore, the theoretical knowledge of fine arts cannot be separated from the study of specialized courses. Both of them play the role of mutual promotion and restriction. For example, many art masters all over the world have changed their knowledge and understanding of specialized courses through studying theoretical courses. The modern abstract painting art of the great abstractist painter Picasso has borrowed and learned the theoretical knowledge and technical skills of African painting. As a result, colleges and universities, as professionals in cultivating a new generation of international painting circles, need teachers to start from the perspective of art theory courses and professional practice and effectively combine the two.

5) Art theory courses through new media teaching. With the development of society and the improvement of people's living standards, electronic science and technology have been applied to various fields of society and have brought changes to people's lives. Nowadays, the new media technology is also applied to art theory teaching in colleges and universities. Therefore, it provides students with a good teaching environment and changes the traditional "board-book" teaching methods. The theory of art course teaching is not just refers to the textbook recitation, also will be combined with the appreciation class to analyze the master of painting works, therefore, the teaching of art theory courses should also use the visual method of teaching, this intuitive art theory teaching method is more effective and more acceptable to the students than the text. Students can see the rich and wonderful aspects of the theoretical knowledge of art and deepen the student's understanding of art theory knowledge. For example: the text describes three different types of New Year Pictures, "Elegant Willow New Year Pictures," "Realistic Peach New Year Pictures," and "Rustic Pine and Cypress New Year Pictures." Teachers can ask students to think of these three New Year pictures in their heads and use art theory Sexual terminology will be the basic characteristics of New Year expression clearly, and finally through the new media and other forms of painting will be presented to students, this not only enhances the students 'imagination and creativity, but also 
enhances students' interest in the theoretical knowledge of fine arts and plays the best of both worlds.

6) The use of independent inquiry teaching mode. In the teaching of art theory course, teachers can adopt the teaching mode according to their aptitude so that students can integrate into the atmosphere of art theory course and learn their own weak places to consolidate the impression of art theory knowledge. Teachers in art theoretical knowledge before teaching, students can be divided into several groups in the classroom to provide students with more time and space for students to understand the theoretical knowledge of art more solid, students through mutual communication and learning, based on the understanding of other students' theory of fine arts, we can make up for the deficiencies of the students, and students can feel the potential charm of the theoretical knowledge of art from the help of each other. Moreover, the self-explored teaching mode will enable students to enhance their understanding of art theory knowledge from the heart and make students more flexible and convenient in using art theoretical knowledge, and narrow the gap between students' understanding of art theoretical knowledge. For example, when teachers explain the theoretical knowledge of post-Impressionist painting, they can ask students to find relevant information in their own classes, discuss them in groups and discuss the characteristics of "postImpressionist painting" and the related masters of painting To sum up, and through the "postImpressionist painting" feature to understand the master's work is how to reflect the post-impression characteristics, so that students express their views, and finally let each group elected a representative to explain and analyze.

\section{Conclusion}

To sum up, this article through two major aspects of a comprehensive interpretation of the theory and practice of college course teaching methods and measures. The author believes that theory is the basis of practice. All practice is transformed from theoretical knowledge. Therefore, neither the teacher nor the student can ignore the mastery of the theoretical knowledge of fine arts. According to the development of the times and the reform of the syllabus, the theory of fine arts curriculum model is constantly changing and updating, in order to cultivate a new generation of talent in the arts, teachers need to continue to explore teaching methods, and constantly update the traditional teaching thinking, with a new look to teach the theory of fine arts and promote student learning Initiative and enthusiasm, so that students will be the theoretical knowledge of art and practical skills to unify.

\section{References}

[1] GAO Xu. Some thoughts on strengthening the teaching reform of the theoretical course of art education in Normal Universities [J]. Popular Literature and Art, 2017 (13): 243-244.

[2] Chen Jian Mao. Thoughts and Strategies for Teaching Reform of Art Theory Courses in Universities [J]. Beauty and Times (the), 2017 (06): 111-113.

[3] Hou Chuan-ching. Analysis of Art Theory Teaching in Universities - The Relationship between Theory and Actual Teaching and Creation [J]. Science and Technology Information, 2012 (02): 310311.

[4] HAN Jing, Cultivating Humanities, Strengthening Aesthetic Education and Promoting Professional Development - Reflections on Teaching Function and Train of Thought of Art Introduction to Art Major [J].

[5] Zhou Guochuan. The Status Quo of the Theses of Graduation Thesis of Fine Arts Education in Local Colleges and Curriculums [J]. Art Education Research, 2014 (01): 123-124.

About the Author: Tana (1981.2), female, Mongolian Hohhot Institute of Nationalities art master's degree, lecturer, engaged in art history, teaching of art 